\title{
SINTESIS CALKON ((E)-1,3-DI(NAPHTHALEN-2-YL)PROP-2-EN-1-ONE) DAN AKTIVITASNYA SEBAGAI ANTIOKSIDAN
}

\author{
Rahmiwati Hilma, Jasril, Hilwan Yuda Teruna
}

\author{
Mahasiswa S-2 pada pasca sarjanakimia Universitas Riau \\ Pembimbing I penelitian. FMIPA, Universitas riau \\ Pembimbing II penelitian, FMIPA, Universitas Riau
}

\begin{abstract}
Study on chalcone calkon (E)-1,3-di(naphthalen-2-yl)prop-2-en-1-one synthesis have been carried out with stirrer methode. These compounds can be used as intermediate compound to synthesize others compounds which was reported having antimicrobial, anti-inflammatory, anti-depressant, anti-tumour. The of chalcones synthesis vatives were reported in acid and alkali condition. In this study, chalcone and its derivates were synthesized by using stirrer method in alkaline condition in room temperature. the compounds subjected to somes analyses including melting point measurement, thin layer chromatography and HPLC. Scavenging free radical by using DPPH methode showed Scavenging free radical with LC50 $>80 \mu \mathrm{g} / \mathrm{ml} \mathrm{min}$ potent activity while the ascorbat acid LC50 89,79 $\mu \mathrm{g} / \mathrm{ml}$.
\end{abstract}

\section{Keywords: Chalcones, Anti-oxidant, DPPH scavenging}

\section{PENDAHULUAN}

Senyawa calkon merupakan salah satu senyawa metabolit sekunder golongan flavonoid yang berpotensi sebagai antibakterial, anti jamur, dan anti-ulcer / sejenis penyakit kulit, bisul (Prasad et al, 2006), antibakteri (Alam, 2004), antikanker (Samoszuk et al,2005; Achanta et al., 2006;Modzelewska et al., 2006), sitotoksisitas, antikolera (Windholz et all, 1996), antiinflamasi (Vender et al, 1993), antitumor (Usman dkk, 2005) dll. Beberapa derivat senyawa calkon dikaji aktivitas sitotoksiknya dengan mengunakan tiga tumor cell lines, yaitu B16 (Murine Melanoma), HCT116 (Human Colon Cancer Cells) and A431 (HumanEpidermoid Carcinoma) (Nam et al., 2004). Selain itu, calkon alami dan sintesis menunjukkan efek antiproliferatif yang kuat terhadap sel kanker ovarian (de Vincenzo et al., 1995) dan gastric cancer HGC-27 cells (Shibata, 1994). Senyawa ini sangat menarik dalam kaitannya dengan penggunaannya sebagai material awal dalam sintesis berbagai jenis senyawa heterosiklik seperti senyawa pirazolin, pirimidin, benzotiazepin, sikloheksanon yang kaya dengan aktifitas biologis.

Senyawa calkon ini dapat diperoleh dengan cara isolasi dari tumbuhan, namun untuk memperolehnya, terdapat beberapa kelemahan antara lain jumlahnya di alam yang terbatas dan persentasenya dalam tumbuhan juga kecil sekitar 3-5\%, variasi strukturnya relatif sedikit, serta membutuhkan biaya yang cukup mahal dan waktu yang cukup lama untuk mengisolasinya. Bertolak dari hal tersebut, maka didapatkan suatu solusi yang dapat meminimalisir segala kekurangan dalam proses isolasi itu yaitu dengan cara sintesis kimia di laboratorium (Alam, 2004).

Dewasa ini, penemuan penelitian berupa senyawa bioaktif dapat dikembangkan menjadi senyawa medisinal unggulan yang bernilai ekonomi tinggi. Penelitian ini sangat penting mengingat di negara maju alur pikir teknologi kesehatan saat ini tidak lagi menggunakan senyawa kimia umum, namun pencarian senyawa kimia alami tunggal atau senyawa murni menjadi prioritas.

Hal ini merupakan salah satu pendorong bagi kami untuk mengembangkan atau merekayasa molekul calkon baik untuk mempelajari sifat fisiko-kimianya atau untuk kepentingan terapeutik. Salah satu metoda sintesis untuk membuat senyawa turunan calkon adalah melalui kondensasi Aldol dari suatu keton aromatik dan aldehid aromatik baik dalam kondisi basa maupun asam. Metoda ini dikenal ramah 
lingkungan (Green Chemistry) karena menggunakan bahan kimia berbahaya yang relatif kecil.

Senyawa calkon mempunyai aktivitas antioksidan yang sangat berpotensial. Antioksidan scavenging radikal DPPH bereaksi dengan radikal bebas stabil, sehingga dalam pengukuran penghilangan warna berhubungan dengan jumlah elektron yang ditangkap. Perubahan pada absorbansi yang dihasilkan dalam reaksi ini digunakan untuk mengukur sifat antioksidan. Hasilnya hampir menyamai aktivitas scavenging radikal bebas dari vitamin C. ( Doan et al.,2011)

Penelitian ini bertujuan mensintesis senyawa calkon dalam penemuannya sebagai salah satu senyawa antioksidan untuk pencegahan penyakit kanker.

\section{METODOLOGI PENELITIAN}

Alat-alat yang digunakan untuk pengerjaan sintesis berupa seperangkat alat destilasi, seperangkat alat rotary evaporator, vial, gelas ukur, bejana kromatografi (camber), corong Buchner, vakum, lampu UV $\square 254 / 366 n m$ (Camag®), aluminium foil, spatel, pipet tetes, timbangan analitik, kertas saring, kapiler, Fisher John Melting Point Apparatus (SMP 11Stuart ${ }^{\circledR}$ ), spektrofotometer UV-Vis (UV-Vis 1800 Shimadzu $\left.{ }^{\circledR}\right)$, spektrometer NMR JEOL EK 500 1H-RMI pada frekwensi $500 \mathrm{MHz}$, spektrometer massa (TOF MS).

Bahan-bahan yang digunakan untuk pengerjaan sintesis berupa 1-Acetylnaphthalene (Merck No Cat. 818468), 2-Naphthaldehyde (Merck No. Cat. 820845), $n$-heksana, etilasetat, diklorometana, Cloroform, metanol, aquadest dingin, $\mathrm{NaOH}$ (Merck No. Cat. 1.06498), etanol p.a.BAhan-bahan yang digunakan untuk uji aktivitas scavenging radikal bebas adalah Asam galat, reagen folin-ciocalteau, 2,2-diphenyl-1picrylhydrazyl (DPPH), asam linoleat, TPTZ (2,4,6-tripydyl-s-triazine) dan asam askorbat yang diproduksi oleh Sigma-Aldrich, Merck dan Fluka.
Sintesis calkon (E)-1,3-di(naphthalen-2yl)prop-2-en-1-one

Campuran yang sesuai dari 1 asetil naftalen (2.5 mmol) dilarutkan dalam 3,75 etanol absolut distirer beberapa menit, kedalam larutan ditambahkan $\mathrm{KOH} 1 \mathrm{~N}$ sebanyak $5 \mathrm{ml}$ sambil distirer. Setelah \pm 5 menit ditambahkan 2 naftaldehid (2,5 mmlo), stirrer dilanjutkan sampai \pm 2 jam. reaksi dimonitor dengan KLT. Setelah 2 jam stirrer dihentikan dan didinginkan di dalam kulkas selama \pm 24 jam. Selanjutnya hasil stirrer di netralkan dengan larutan $\mathrm{HCl} 1 \mathrm{~N}$, dan disaring. Padatan dicuci dengan air dingin untuk menghilangkan $\mathrm{NaOH}$ dan rekristalisasi dengan etanol. Kemudian ditentukan kemurnian dan titik jarak Kristal.

\section{Karakterisasi senyawa sintesis}

Karakterisasi senyawa meliputi pemeriksaan organoleptis (yaitu pemeriksaan bentuk padatan dan warna), dan pemeriksaan kemurnian (pemeriksaan jarak leleh, kromatografi lapis tipis, dan analisa HPLC).

\section{Analisis Aktivitas Antioksidan}

Analisis aktivitas antioksidan dilakukan dengan empat uji yaitu uji 2,2-diphenyl-1picrylhydrazyl (DPPH), uji Ferryc Reducing Antioxidant Power (FRAP), dan uji oksidasi asam linoleat.

\section{Analisis total aktivitas antioksidan dengan uji DPPH}

Kandungan total aktivitas antioksidan diukur dengan uji DPPH (Gil dkk., 2000). Kristal 2,2diphenyl-1-picrylhydrazyl (DPPH) $\quad(2,4 \quad \mathrm{mg})$ dilarutkan dalam metanol 80\% (100 mL). Larutan DPPH ( $3 \mathrm{~mL}$ ) ditambah dengan larutan sampel (1 $\mathrm{mL})$. Campuran dikocok dan diinkubasi selama 15 menit pada temperatur ruang. Absorbansi sampel diukur pada panjang gelombang $515 \mathrm{~nm}$ menggunakan spektrofotometer dan hasilnya dihitung dalam asam askorbat ekivalen (AAE $\mathrm{mg} / \mathrm{g}$ ) menggunakan kurva standar asam askorbat. 
$\mathrm{Y}=\mathrm{aX}+\mathrm{b}$

$\mathrm{Y}=$ absorbansi sampel

$\mathrm{X}=$ konsentrasi sampel

konsentrasi sampel $\mathrm{x}$ jumlah pelarut $\mathrm{x}$ faktor pengenceran

Aktivitas Antioksidan =

$$
\text { berat sampel }
$$

(Absorbansi kontrol - Absorbansi sampel)

$\%$ Hambatan=

\section{Absorbansi control}

\section{HASIL DAN PEMBAHASAN}

HASIL

Sintesis calkon (E)-1,3-di(naphthalen-2yl)prop-2-en-1-one

Hasil sintesis diperoleh berupa serbuk berwarna kuning dengan rendemen $83,3 \%$. Jarak leleh: $76-78{ }^{\circ} \mathrm{C}$. Hasil pengujian menggunakan KLT didapat harga Rf: 0,75 dengan sistem eluen $n$-heksana: etil asetat $(9: 1)$.

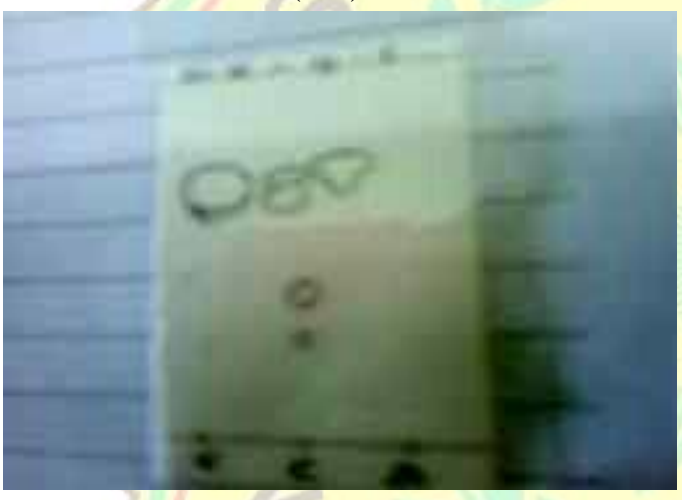

Gambar 1. Hasil KLT dari sampel setelah distirer selama \pm 2 jam

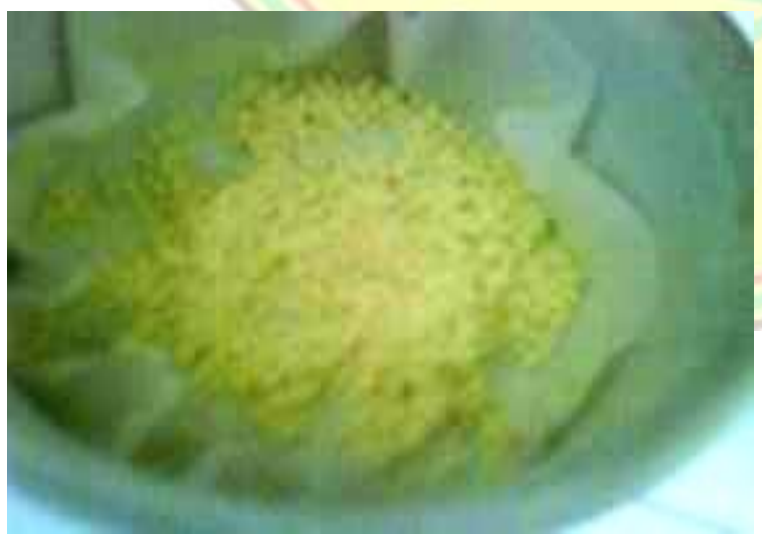

Gambar 2. sampel setelah disaring $=1.426 \mathrm{gr}$ dengan rendemen $=91.8 \%$

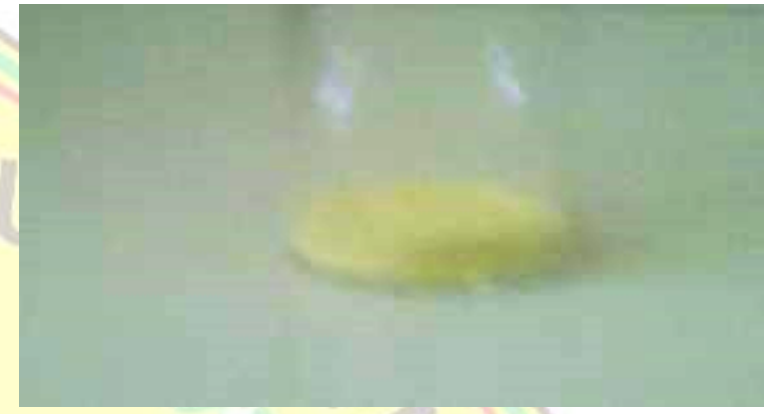

\section{Gambar 3. Hasil dari rekristalisasi sampel} dengan etanol

Berat sampel setelah direkris $=0.527$ gr dengan rendemen $83,3 \%$, TTL $=76-78{ }^{\circ} \mathrm{C}$

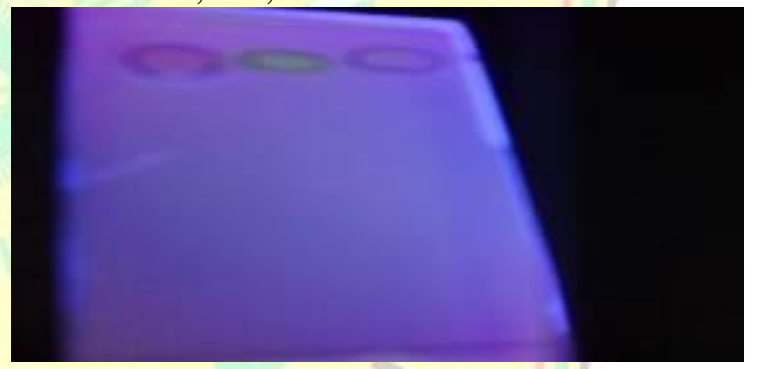

Gambar 3. Spot yang paling kiri adalah 1asetilnaftalen, Spot yang paling kanan adalah 2-naftaldehid, Spot yang ditengah-tengah adalah calkon (E)-1,3-di(naphthalen-2yl)prop-2-en-1-one

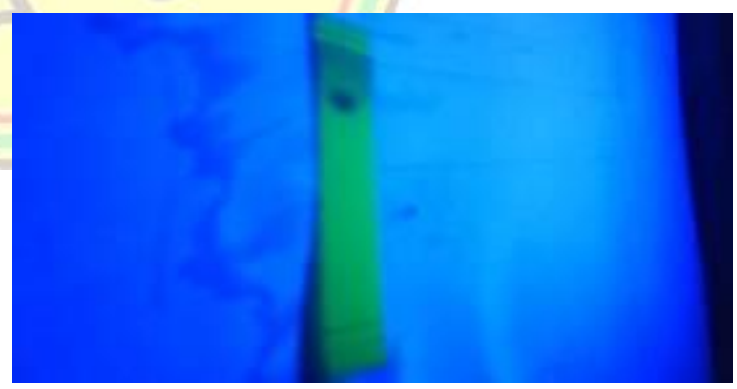

Gambar. 4. Spot dari calkon (E)-1,3di(naphthalen-2-yl)prop-2-en-1-one 


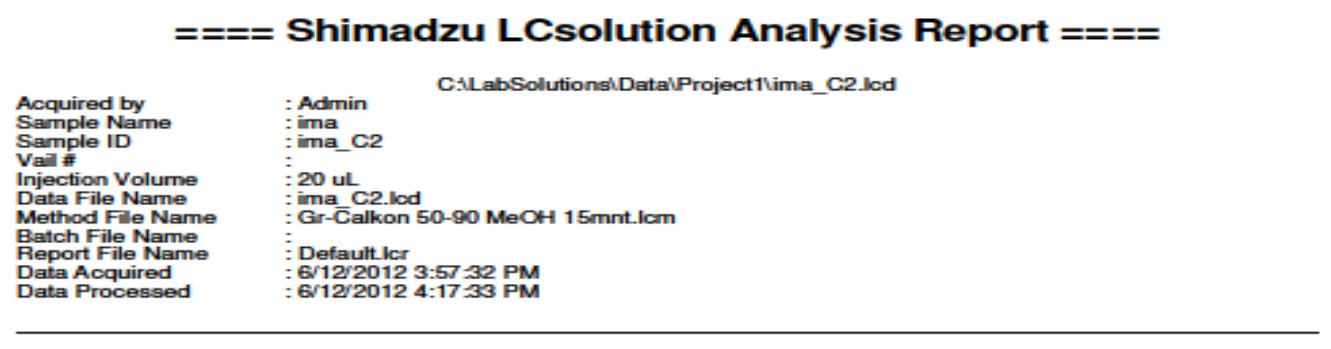

<Chromatogram
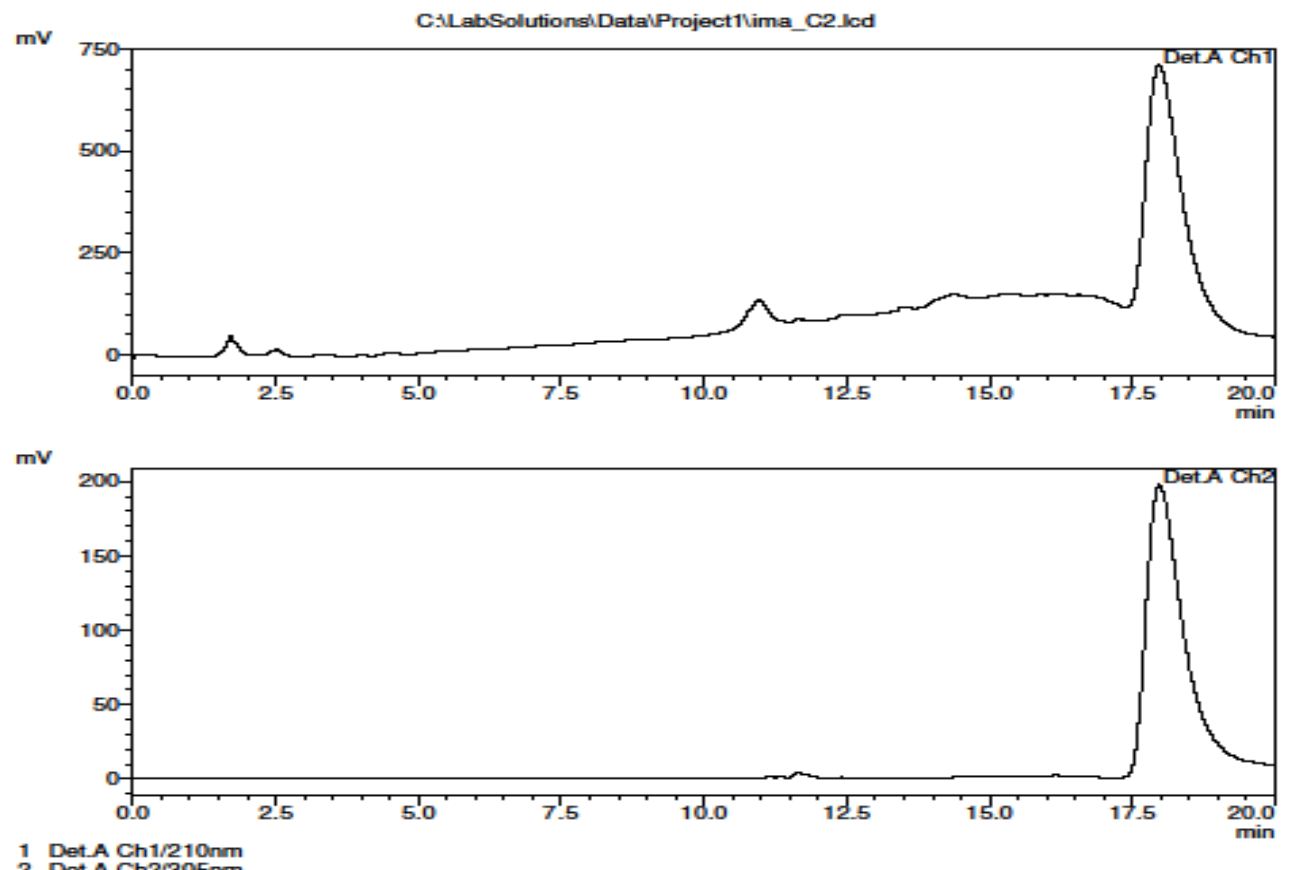

1 Det.A Ch1/210nm

Penentuan aktivitas antioksidan

Persentase hambatan aktivitas antioksidan pada sampel calkon (E)-1,3-di(naphthalen-2- yl)prop-2-en-1-one menggunakan metode 2,2'dipheyil-1-picriylhydrazil (DPPH) disajikan pada Tabel 1.

Tabel 1. Aktivitas antioksidan (E)-1,3-di(naphthalen-2-yl)prop-2-en-1-one dengan uji DPPH dan nilai $\mathrm{IC}_{50}$.

\begin{tabular}{llllll}
\hline No & Sampel & \multicolumn{1}{c}{$\begin{array}{c}\text { Konsentrasi } \\
(\mathbf{p p m})\end{array}$} & Absorbansi & \% Hambatan & IC50 (ppm) \\
\hline \multirow{2}{*}{ Calkon } & 1000 & 0.289 & 7.302 & \\
& & 500 & 0.293 & 5.682 & \\
& 250 & 0.294 & 5.093 & $>80$ \\
& 125 & 0.295 & 4.945 & \\
& 62.5 & 0.297 & 4.061 & \\
& 31.25 & 0.302 & 1.557 &
\end{tabular}




\begin{tabular}{llllll}
\hline No & Sampel & \multicolumn{1}{c}{$\begin{array}{c}\text { Konsentrasi } \\
(\mathbf{p p m})\end{array}$} & Absorbansi & \% Hambatan & IC50 (ppm) \\
\hline \multirow{3}{*}{2} & & & & \\
& \multirow{2}{*}{ Asam askorbat } & 50 & 0.099 & 87.279 \\
& 25 & 0.112 & 83.022 \\
& 12.5 & 0.182 & 61.319 & 9.79 \\
& 6.25 & 0.244 & 42.108 & \\
\hline
\end{tabular}

\section{PEMBAHASAN}

Pada penelitian ini digunakan metode uji aktivitas antioksidan adalah metode DPPH (2,2'diphenyl-1-picrylhydrazyl). Metode DPPH berdasarkan pada aktivitas antioksidan dalam menghambat radikal bebas melalui Hydrogen Atom Transfer. Mekanisme ini berdasarkan pada kemampuan antioksidan menetralkan radikal bebas dengan cara mendonorkan atom $\mathrm{H}$ (Apak et al., 2007), sehingga warna ungu pada DPPH berubah menjadi warna kuning. Gulcin (2006) mengatakan bahwa terjadi absorbansi yang rendah ketika radikal DPPH dihambat oleh senyawa antioksidan melalui proses donor hidrogen, untuk membentuk radikal yang stabil, sehingga terjadilah perubahan warna kuning yang sebelumnya berwarna ungu. Pada uji radikal DPPH ini dilakukan dengan mengukur absorbansi dengan panjang gelombang $520 \mathrm{~nm}$. Pada penelitian terhadap uji DPPH senyawa hasil sintesis calkon (E)-1,3-di(naphthalen-2-yl)prop2-en-1-one memperlihatkan aktivitas antioksidan yang lemah, ditandai dengan nilai $\mathrm{IC}_{50}$ lebih besar dari 80 ppm (Tabel 4.1). Sedangkan untuk standar digunakan asam askorbat dengan nilai $\mathrm{IC}_{50} 9,79$ ppm. Hasil ini dapat disebabkan tidak adanya gugus fungsi pada senyawa hasil sintesis yang dapat berperan untuk menangkap radikal bebasnya, semakin banyak gugus fungsi (lebih baik untuk fenolik), maka semakin besar juga kemampuan suatu antioksidan untuk menetralisir radikal DPPH. Semakin kecil nilai $\mathrm{IC}_{50}$ berarti semakin tinggi aktivitas antioksidan (Molyneux, 2004; Andayani et al., 2008).

Dari metode ini memperlihatkan bahwa senyawa calkon (E)-1,3-di(naphthalen-2-yl)prop2-en-1-one memiliki hambatan yang kecil sebagai antioksidan. Hal ini didasarkan pada hasil uji aktivitas yang memperlihatkan hambatan yang sangat kecil meskipun telah menggunakan konsentrasi yang tinggi. Metode DPPH merupakan uji secara langsung terhadap senyawa yang bersifat radikal (Gulcin, 2006. Persen hambatan radikal DPPH lebih tinggi, maka senyawa pada sampel lebih bersifat sebagai pendonor elektron dan dapat menetralisir radikal bebas (Lindsey et al., 2002; Molyneux, 2004).

Kemampuan aktivitas antioksidan suatu sampel disebabkan karena adanya senyawasenyawa yang memiliki gugus aktif (lebih baik pada gugus hidroksi) yang dapat bersifat sebagai antiradikal bebas, dengan cara mendonorkan elektron yang tidak berpasangan kepada senyawa radikal bebas sehingga radikal bebas menjadi stabil. Senyawa yang berpotensi sebagai antioksidan alami yaitu senyawa-senyawa fenolik, salah satu golongannya adalah senyawa flavonoid. Semakin banyak senyawa flavonoid dan fenolik di dalam suatu sampel, maka semakin tinggi pula aktivitas antioksidannya (Chang and Xu., 2007).

\section{KESIMPULAN DAN SARAN}

Dari hasil penelitian sintesis senyawa calkon (E)-1,3-di(naphthalen-2-yl)prop-2-en-1-one dapat diambil kesimpulan bahwa:

1. Metode Stirer lebih tepat digunakan untuk mensistensis senyawa ini karena hasil yang didapatkan memiliki rendeman yang lebih tinggi.

2. Hasil uji aktivitas antioksidan terhadap senyawa calkon (E)-1,3-di(naphthalen-2yl)prop-2-en-1-one menggunakan metode DPPH menunjukkan presentase hambatan yang kecil $\left(\mathrm{IC}_{50}>80 \mathrm{ppm}\right)$ jika dibandingkan dengan persentase 
hambatan asam askorbat ((IC) 9,79 ppm)

Berdasarkan hasil penelitian ini penulis menyarankan agar dilakukan Uji karakterisasi senyawa dengan spektroskopi NMR, MS, dan IR. Penelitian lebih lanjut terhadap senyawa ini perlu dilakukan untuk mendapatkan keaktifan senyawa yang lebih baik dengan cara mereaksikannya dengan senyawa fenilhidrazin (reaksi tahap dua) untuk membentuk pirazolin dan melakukan uji aktivitas yang lain terhadap senyawa calkon (E)1,3-di(naphthalen-2-yl)prop-2-en-1-one dan pirazolin seperti Uji pendahuluan aktivitas sitotoksik dengan metoda Brine Shrimps Lethality Test (BSLT), Uji aktivitas antikanker secara in vivo dengan metoda Micronucleuos Assay.

\section{DAFTAR PUSTAKA}

Achanta, G., Modzelewska, A., Feng, L., Khan, S.R., Huang, P., 2006, “A Boronic-chalcone Derivative Exhibits Potent Anticancer Activity through Inhibition of the Proteasome", Molecular Pharmacology, 70(1), 426-433.

Anomimous, "Artemia salina (Brine shrimp)",http://ofish.com/artemia,Accessed date 3 Mei 2007.

Amarowicz, R., Estrella, I., Hernandez, T., Robredo, S., Troszynska, A., Kosinska, A., Pegg, R.B. 2010. Free Radical-Scavengning Capacity, Antioxidant Activity, and Phenolic Composition of Green Lentil (Lens culinaris). Food Chemistry. 121: 705 - 711

Ayo, R.G, J.O. Amupitan, Y. Zhao, 2007, "Cytotoxicity and Antimicrobial Studies of 1,6,8-trihidroxy-3-methyl-antraquinone (emodin) Isolated from the Leaves of Cassia nigricans vahl", African Journal of Biotechnology, 6(11), 1276-1279.

Banday, A.H., Mir, B.P., Lone, I.H., Suri, K.A., Kumar, H.M., 2010, "Studies on novel Dring Substituted Steroidal Pyrazolines as Potential Anticancer agents", Steroids, 75, 805-809.
Bag, S., Ramar, S., degani, M.S., 2009, "Synthesis and Biological Evaluation of $\alpha, \beta$ Unsaturated Ketone as Potential Antifungal Agen”, Med Chem. Res., 18, 309-316.

Busk, L.B., Sjostrom, Ahlborg, U.G., 1984, "Effect of Vitamin A On Cyclophospamida Mutageneticity in Vitro (Ames Test) and in Vivo (Mouse Micronucleus Assay), Fd Chem. Toxic, 22.

Claisen, L., Claparede, A., Schmidt, J.G, 1881, "Condensation of Aromatic Aldehydes and Aliphatic Aldehydes or Ketones in The Presence of Aqueous Base", Ber, 14:2460, 1459.

Cho, S.J, H.L. Valerie, S.H. Wu-Sing, K.Y. Sing, J.P. Pereira, dan S.H. Goh, 1998, "Novel Cytotoxic Polyprenilaterd Xanthones From Garcinia gaundichaudii (Guttiferae)", Tetrahedron, 54, 10915-10924.

Farmer, P.B. and J.M. Walker, 1985, The Molecular of Cancer, Croom Helm,London.

Fox, R., 2004, Static Acute Toxicity Bioassay Laboratory Exercises, Laboratory: Ecologi pages, 306.

Gritter, R.J., 1991, J.M Bobbit, A.E Schwarting, Pengantar kromatografi, ITB, Bandung.

Guyton, A. C., Hall, J. E., 1997, "Pengaturan Fungsional Tubuh Manusia dan Pengaturan "Lingkungan Dalam" dalam Buku Ajar Fisiologi Kedokteran, Alih Bahasa I. Setiawan, K. A. Tengadi dan A. Sentoso. Ed. 9, EGC, Jakarta, Hal.3-51.78

Havrylyuk, D., Zimenkovsky, B., Vasylenko, O., Zaprutko, L., Gzella, A., Lesy,R., 2009, "Synthesis of Novel Thiazolone-Based Compounds Containing Pyrazoline Moiety and Evaluation of Their Anticancer Activity", European Journal of Medicinal Chemistry, 44, 1396-1404

Hostettmann, K., A. Marston, M. Hostettmann, 1997, Preparative Chromatography Techniques, 2rd completely rev. and enl. ed,University of Lausanne, Switzerland. 
Iijima, Y., Suda, K., Suzuki, T., Aoki, K., Shibata, D., 2008, "Metabolite Profiling of Chalcones and Flavanones in Tomato Fruit", J. Japan. Soc. Hort.Sci., 77 (1), 94-102. 2008.

Krishnaraju, A.V, Tayi V.N Rao, D. Sundararaju, M. Vanisree, H.S Tsay, G.V. Subbaraju, 2005, "Assesment of Bioactivity of Indian Medicinal Plant Using Brine Shrimp (Artemia salina) Lethality Assay", International Journal of Applied Science and Engineering, 3(2), 125-134.

Kromann, H., Larsen, M., Boesen, T., Schønning, K., Simon Feldbæk Nielsen, S.F., 2004, "Synthesis of prenylated benzaldehydes and their use in the synthesis of analogues of licochalcone A, European Journal of Medicinal Chemistry, 39(11), 993-1000.

Kidwai, M., Kukreja S., Thakur R., 2006, "K2CO3-Mediated regioselective synthesis of isoxazoles and pyrazolines", Lett Org Chem, 3, 135. Li, J.-T., Yang, W.-Z., Wang, S.-X, Li, S.-H, Li, T.-S., 2002, "Improved Synthesis of Chalcones Under Irradiation", 1trasonics Sonochemistry, 9, 237-239.

Lévai, A., 2005, "Synthesis of chlorinated 3,5diaryl-2-pyrazolines by the reaction of chlorochalcones with hydrazines", ARKIVOC, 9, 344-352

Modzelewska, A., Pettit, C., Achanta, G., Davidson, N.E., Huang, P., Khan, S.R.,2006, "Anticancer Activities of Novel Chalcone and bis-Chalcone Derivatives", Bioorganic \& Medicinal Chemistry, 14, 3491-3495.

Meyer, B. N. R Ferrigni, J.E Putnam L, B Jacobsen, D, E, Nicholas, and J L. Mc, laughin, 1982, "Brine Shrimp: A convenient General Bioassay For Active Plant Constituens", J. of Medical Plant Medica, 45, 31-34.

Narender, T., Papi Reddy, K.A., 2007, "Simple and Highly Efficient Method for the Synthesis of Chalcone by Using
Borontrifluoride-etherate, Tetrahedron Lett, 48, 3177-3180.

Nowakowska, Z., 2007, "A Review of Antiinfective and Anti-inflammatory Chalcone", European Journal of Medicinal Chemistry, $42,125-137$

Ozdemir, A., Zitouini, G.T., Kaplancikli, Z.A., 2008, "Novel analogues of 2-pyrazoline: Synthesis, Characterization and Antimicrobacterial Evaluation", Turk J. Chem., 32, 529-538.

Pisutthanan, S, P. Plianbangchang, N. Pisutthanan, S. Ruanruay, O. Muanrit, 2004, "Brine Shrimps Lethality Activity of Thai Medicinal Plants in the Family Meliaceae", Naresuan University Journal, 12(2), 13-14.

Powers, D.G., Casebier, D.S., Fokas, D., Ryan, W.J., Troth, J.R., Coffen, D.L., 1998, "Automated parallel synthesis of chalconebased screening libraries", Tetrahedron Lett, 54, 4085-4096.

Rateb, N.M and Zohdi, H.F, 2009, "AtomEfficient, Solvent-Free, Green Synthesis of Chalcones by Grinding", Synthesis Communications, 39,2789-2794.

Sastrohamidjojo, H., 1991, Dasar-dasar Spektroskopi, Ed II, Liberty, Universitas Gajah Mada, Yogyakarta.

Sharp, J., I. Gosney, A.G Rowley, 1989, Practical Organic Chemistry: A Student Handbook of Techniques, Chapman and Hall, London.

Singh,S., Sharma,P.K., Kumar,N., Dudhe,R., 2011. Anti-oxidant Activity of 2hydroxyacetophenone Chalcone. Journal of Advanced Scientific Research. 2(3): 37-41. Meerut Institute of Engineering \& Technology.India

Doan,T.N., Tran,D.T.,2011. Synthesis, Antioxidant and Antimicrobial Activities of a Novel Series of Chalcones, Pyrazolic Chalcones, and Allylic Chalcones. Pharmacology \& Pharmacy, 2, 282-288 
Yoshihara, D., Fujiwara, N., Suzuki, K. 2010. Antioxidants: Benefits and risks for long- term health. Maturitas. G Model MAT5378: 5-10

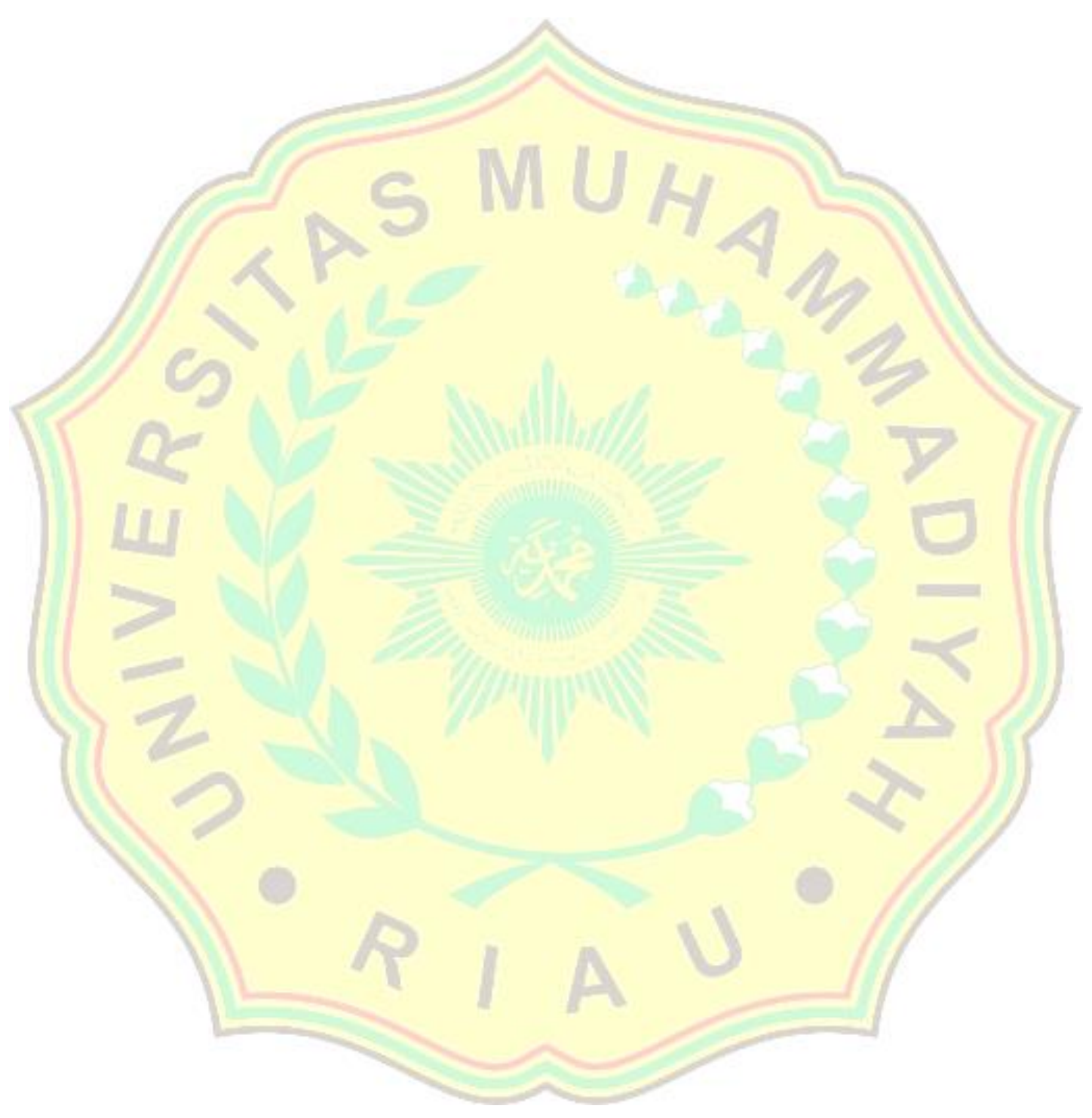

